\title{
Sterilization of the biological safety cabinet
}

\author{
S. W. B. NEWSOM AND B. M. WALSINGHAM \\ From the Sims Woodhead Memorial Laboratory, Papworth Hospital, Papworth Everard, \\ Near Cambridge
}

SYNOPSIS Test strips comprising $B$ subtilis spores or $M$ phlei cells dried on aluminium foil (some serum-coated) were used to test sterilizing processes currently advised for safety cabinets. Exposure to formalin from a bowl, boiling excess formalin with the fan running, and ultraviolet radiation were all found to be unreliable, as was glutaraldehyde. Vaporization of $2 \mathrm{ml}$ of formalin per $0.028 \mathrm{~m}^{3}$ followed by exposure for 18 hours at ambient temperatures was $100 \%$ successful, and the depolymerization of paraformaldehyde tablets with a hair drier was a simple, very effective alternative method.

Effective methods are needed for the sterilization of biological safety cabinets: for filters, surfaces, and contents. The methods commonly used areshort wave ultraviolet irradiation ( $2537 \AA$ ), formaldehyde or glutaraldehyde. Most cabinets currently available have an ultraviolet source, and two models are provided with formalin vaporizers. The published work on ultraviolet irradiation deals mainly with wet microbes in fluids or aerosols (Schechmeister, 1968). The rays are undoubtedly bactericidal but species vary in susceptibility and mycobacteria are relatively resistant (Collins, 1971). However, the removal of bacteria contained in aerosols inadvertently liberated inside a cabinet is a function of the filters. The bacteria remaining on the inner surfaces are likely to be dry and covered in protein, as for example, in sputum. The value of ultraviolet under such conditions is uncertain and so formalin vapour (Darlow, 1967) has been used instead; Evans and HarrisSmith (1970) used glutaraldehyde where deposition of formalin polymers was troublesome. Finally Taylor, Barbeito, and Gremillion (1969) sterilized surfaces by depolymerization of paraformaldehyde. Our paper describes a comparative trial of these methods in various safety cabinets currently available.

\section{Materials and Methods}

Cabinets were kindly lent by Engineering Developments Ltd (EDL), Farnborough, Hants, Laboratory and Thermal Electric Co (LTE), Oldham, Lancs, Microflow Ltd, Minley, Hants, Phase-Separations Received for publication 14 August 1974.
Co, Queensferry, Flint, and the South London Electric Co, Lewisham. The Public Health Laboratory Service (LEEC) 1970 model was also used.

Test strips were made with Bacillus subtilis var globigii (NCTC No. 10075) spores or cells of Mycobacterium phlei dried from distilled water on squares of aluminium foil. Some strips were coated with horse serum. Viable bacteria on the strips were resuspended in peptone water with an ultrasonic vibrator (Dawe Instruments) and surface viable counts were obtained by a drop-counting method. Strips were distributed throughout the test cabinets and exposed to various sterilizing processes.

Formaldehyde was used as liquid formalin $(40 \%$ Solmedia) or as a vapour generated from either neat or $50 \%$ formalin in water by heat from a hotplate, a gas burner, or a thermostatically controlled electric vaporizer. Paraformaldehyde tablets $(1 \mathrm{~g})$ were depolymerized by exposure to hot air from a hair drier (Morphy-Richards) for two hr (Meers, 1974) and humidity was added with a small cube of wet sponge. Glutaraldehyde was vaporized by boiling a $20 \%$ solution. No other moisture was added. Formaldehyde and glutaraldehyde were neutralized by dipping the strips in $1 \%$ sodium bisulphite, which did not affect the viability of the dried bacteria, and survivors were recovered by growth in brain-heart infusion (Difco) for three days at $37^{\circ} \mathrm{C}$. Formalin vapour concentration was measured by Braymen and Songer's (1970) method; 301 of air was passed through a Porton raised-capillary impinger containing $20 \mathrm{ml} \mathrm{M}$ sodium sulphate, which was then titrated with $0 \cdot 1 \mathrm{~N}$ sulphuric acid with thymolphthalein as an indicator. 
The cabinets were equipped with new 15 watt ultraviolet sources, usually slung from the roof, and thus about $0.6 \mathrm{~m}$ above the floor. Ultraviolet radiation was measured in $\mu \mathrm{W} / \mathrm{cm}^{2}\left(10 \mathrm{ergs} / \mathrm{sec} / \mathrm{cm}^{2}\right)$ with a J-225 Blak Ray short wave meter (Shandon Scientific Company). Readings were taken from nine sites on the floor of each cabinet.

\section{Results}

\section{ULTRAVIOLET RADIATION}

\section{Intensity levels}

The levels obtained varied by at least a factor of twofold for different sites on floor of the same cabinet. The unit supplied with two $15 \mathrm{~W}$ sources had a level of $220 \mu \mathrm{W} / \mathrm{cm}^{2}$ in the centre; the others were equipped with one source which produced levels ranging from 120 to $260 \mu \mathrm{W} / \mathrm{cm}^{2}$ centrally and 40 to 60 at the edges.

\section{Bactericidal effect}

Test strips with $2 \times 10^{6} \mathrm{M}$. phlei or $2 \times 10^{5}$ spores were exposed to ultraviolet rays in two cabinets in sets of three. The strips were placed on the floor and $2 \cdot 5,5$, and $7 \cdot 5 \times 10^{-2} \mathrm{~m}$ above it and were exposed for one, two, four, eight, and 24 hours. The radiation intensity varied from 60 to $120 \mu \mathrm{W} / \mathrm{cm}^{2}$. Nevertheless exposure of eight hours in cabinet $A$ and $24 \mathrm{hr}$ in cabinet B was required to sterilize the $M$. phlei strips while $25 \%$ of unprotected and all the serumcoated spore strips survived 24 hours.

Quantitative tests were therefore performed as follows. Spore strips were exposed to $60 \mu \mathrm{W} / \mathrm{cm}^{2}$ in sets of six for 0.5 , one, two, four, eight, and 24 hours. The surviving cells were resuspended and the numbers compared with those on the control strips. The counts after $24-\mathrm{hr}$ exposure were still similar to

\begin{tabular}{llllllllll}
\hline & $\begin{array}{l}\text { No. of } \\
\text { Cells }\end{array}$ & \multicolumn{6}{c}{ Exposure to Ultraviolet (hours) } \\
\cline { 3 - 9 } & & 0 & 1 & 3 & 4 & 8 & 24 & \\
\hline \multirow{4}{*}{ M. phlei } & $10^{5}$ & 4 & 4 & 4 & 4 & 4 & 4 & \\
& $10^{4}$ & 4 & 4 & 4 & 4 & 3 & 0 & \\
& $10^{3}$ & 4 & 2 & 4 & 3 & 0 & 0 & \\
& $10^{2}$ & 4 & 1 & 2 & 0 & 0 & 0 & \\
& $10^{1}$ & 0 & 0 & 0 & 0 & 0 & 0 & \\
& $10^{5}$ & 4 & 4 & 4 & 4 & 4 & 0 & $(4)$ \\
& $10^{4}$ & 4 & 4 & 4 & 3 & 1 & 0 & $(4)$ \\
& $10^{3}$ & 4 & 3 & 0 & 1 & 0 & 0 & $(3)$ \\
& $10^{2}$ & 4 & 1 & 0 & 0 & 0 & 0 & $(1)$ \\
& $10^{1}$ & 4 & 0 & 0 & 0 & 0 & 0 & $(1)$ \\
\hline
\end{tabular}

Table I Effect of exposing strips containing the indicated number of bacteria to $60 \mu \mathrm{W} / \mathrm{cm}^{2}$ ultraviolet radiation for the time indicated ${ }^{1}$

${ }^{1}$ Numbers $=$ no (out of four) showing growth. ( ) indicate number (out of four) of serum-coated strips with growth. those of the controls. Tenfold dilutions of the two bacterial suspensions were used to prepare more test strips, half of which were serum-coated. Sets of four were exposed to $60 \mu \mathrm{W} / \mathrm{cm}^{2}$ for periods from one to $24 \mathrm{hr}$ and then cultured. The results, which are shown in table I, demonstrated a clear number-dose relationship; four hours' exposure was required to kill $10^{3} \mathrm{M}$. phlei cells.

\section{FORMALDEHYDE}

Vapour from liquid formalin at ambient temperature Test strips with $10^{1}, 10^{4}$ spores and $10^{2} \mathrm{M}$. phlei were not sterilized after exposure to vapour from $100 \mathrm{ml}$ formalin left in a bowl overnight inside a $0.2 \mathrm{~m}^{3}$ cabinet at ambient temperature. The formaldehyde vapour concentration was $0.009 \mathrm{~g} / \mathrm{m}^{3}$.

\section{Vapour from heated formalin}

The EDL and LTE cabinets, both $0.38 \mathrm{~m}^{3}$, were equipped with thermostatically controlled formalin vaporizers. Formalin-neat or with an equal volume of water-was vaporized and sets of 64 test strips were exposed for $18 \mathrm{hr}$ at ambient temperature. The results are shown in table II; $52 \mathrm{ml}$ of $50 \%$ or $25 \mathrm{ml}$ of neat formalin sufficed to sterilize all the strips, including those placed above the prefilters (which were clean). Table III shows the results of shorter exposures and use of larger volumes of formalin with the cabinets unsealed and the fans running.

\begin{tabular}{|c|c|c|c|c|c|}
\hline \multirow[t]{3}{*}{ Model } & \multirow{3}{*}{$\begin{array}{l}\text { Formalin } \\
\text { Vaporized } \\
(\mathrm{ml})\end{array}$} & \multicolumn{4}{|c|}{ Growth Total Strips Exposed } \\
\hline & & \multicolumn{2}{|c|}{ M. phlei } & \multicolumn{2}{|c|}{ B. subtilis } \\
\hline & & Plain & + Serum & Plain & -Serum \\
\hline \multirow[t]{2}{*}{ LTE } & 13 & $1 / 10$ & - & $8 / 10$ & - \\
\hline & 26 & $0 / 16$ & $0 / 16$ & $0 / 16$ & $0 / 16$ \\
\hline \multirow[t]{2}{*}{ EDL } & 13 & $0 / 3$ & $0 / 3$ & $1 / 3$ & $2 / 3$ \\
\hline & 25 & $0 / 16$ & $0 / 16$ & $0 / 16$ & $0 / 16$ \\
\hline
\end{tabular}

Table II Effect of exposing test strips to formalin vapour in $0.38 \mathrm{~m}^{3}$ cabinets for $18 \mathrm{hr}$

\begin{tabular}{llc}
\hline $\begin{array}{l}\text { Formalin } \\
\text { Vaporized }(\mathrm{ml})\end{array}$ & $\begin{array}{l}\text { Exposure Time } \\
(\mathrm{hr})\end{array}$ & $\begin{array}{l}\text { Growth Total } \\
\text { Strips Exposed }\end{array}$ \\
\hline 25 & 1 & $4 / 4$ \\
& 2 & $0 / 4$ \\
14 & 4 & $0 / 4$ \\
100 hot plate & 8 & $11 / 20$ \\
$\quad$ (fan running) & 1 & $1 / 9$ \\
100 Bunsen & & $16 / 16$ \\
\hline
\end{tabular}

Table III Test strips (B. subtilis $10^{4}$ ) exposed to formalin vapour under different conditions in a $0.38 \mathrm{~m}^{3}$ cabinet $(E D L)$ 
Two-hr exposure to vapour from neat formalin $\left(2 \mathrm{ml} / 0.028 \mathrm{~m}^{3}\right)$ was sporicidal, but eight-hr exposure to the $50 \%$ formalin was not always successful. Tests with the fan running indicated that this was also unreliable. Vaporization of $25 \mathrm{ml}$ neat formalin in the EDL cabinet produced a concentration of $0.048 \mathrm{~g} / \mathrm{m}^{3}$.

\section{PARAFORMALDEHYDE TABLETS}

The hair drier produced a temperature of $72^{\circ} \mathrm{C}$ on the tablets and $53^{\circ} \mathrm{C}$ inside the cabinet. A $1 \mathrm{~g}$ tablet was reduced to $0.65 \mathrm{~g}$ after one $\mathrm{hr}$ and to a few crumbs after exposure for two hours to the air stream. The results of tests on a $0.2 \mathrm{~m}^{3}$ (Phasesep) and a $0.34 \mathrm{~m}^{3}$ (Microflow) cabinet are shown in table IV, and it can be seen that heating four tablets for two hours followed by exposure for $22 \mathrm{hr}$ to the vapour sterilized all the serum-coated strips $(2 \times$ $10^{4}$ spores), and that total exposure for one hour was bactericidal for unprotected strips. The formalin vapour concentration in the Phasesep cabinet was $0.044 \mathrm{~g} / \mathrm{m}^{3}$ after one $\mathrm{hr}$ of heating the tablets.

\begin{tabular}{llllc}
\hline Cabinet & $\begin{array}{l}\text { Heating } \\
\text { Time }(\text { hr })\end{array}$ & $\begin{array}{l}\text { Exposure } \\
\text { Time }(\text { hr })\end{array}$ & $\begin{array}{l}\text { Growth Total } \\
\text { Strips Exposed }\end{array}$ \\
\cline { 3 - 5 } & & 1 & Plain & + Serum \\
\hline Phasesep & 1 & 22 & $0 / 6$ & $16 / 16$ \\
Microflow & 2 & 22 & $0 / 12$ & $0 / 16$ \\
\hline
\end{tabular}

Table IV Test strips (B. subtilis $10^{4}$ ) exposed to depolymerized paraformaldehyde in two cabinets $\left(0 \cdot 2\right.$ and $\left.0.34 \mathrm{~m}^{3}\right)$

\section{GLUTARALDEHYDE}

One and $10 \mathrm{ml}$ per $0.028 \mathrm{~m}^{3}$ plus an equal volume of water were boiled off in a $0.2 \mathrm{~m}^{3}$ cabinet. Strips with $10^{3}$ and $10^{6} \mathrm{~B}$. subtilis spores (unprotected) were exposed for $18 \mathrm{hr}$ at ambient temperature and 20 out of the 36 produced growth on culture.

\section{Discussion}

The bactericidal effect of ultraviolet radiation has been known for a century, and was put on a scientific basis by Gates (1929). However, its use in safety cabinets seems illogical because the bacterial contaminants are likely to be dry and covered by protein. Collins (1971) exposed moist bacteria on plates to ultraviolet radiation and found that mycobacteria, in particular $M$. phlei, resisted inactivation more than other vegetative bacteria. Morris (1972) found that dry B. subtilis spores and Serratia marcescens cells suspended in blood were both more resistant than the fresh forms in distilled water.
Finally our work shows that radiation can only be relied on to sterilize mycobacteria after overnight exposure. Even then complications arise: the bacteria may lie in the shadow of apparatus or fittings, the ultraviolet tubes quickly become dirty and ineffective and are outdated after 1000 hours. An outdated tube looks normal; indeed a long wavelength tube emits a similar light and fits the same holders as we discovered when first testing our meter. An electrician had inadvertently fitted the wrong replacement tube in one of our cabinets. Morris (1972) wisely stated: 'The limitations of ultraviolet radiation and its effectiveness when used for safety cabinet disinfection are not always apparent.'

Darlow (1967) recommended formalin for safety cabinet sterilization, and all our test strips were inactivated by exposure to vapour from $2 \mathrm{ml}$ formalin per $0.028 \mathrm{~m}^{3}$ of space after 18 hours' exposure at ambient temperature. No added humidity was used. Vaporization of larger volumes causes deposition of polymers in the cabinet, which may damage equipment or presumptively block filters. Vaporization of formalin while the fan was running was unsuccesful, presumably because of excessive air dilution. Glutaraldehyde also failed, probably because we used too little and too low a temperature. The cabinet contents became very wet with this method. Dissipation of fumes was also a problem with the recycling type of cabinet, which pumped them back into the laboratory; indeed ours was uninhabitable for two days after one glutaraldehyde run.

Surface disinfection with paraformaldehyde was discussed by Taylor et al (1969) who depolymerized the powder in electric frying pans at $232^{\circ} \mathrm{C}$ and sterilized large rooms with an exposure for one hour to $0.3 \mathrm{~g}$ per $0.028 \mathrm{~m}^{3}$. They concluded that the dry gas was a better biocide than vaporized formalin; it was easily dissipated and did not leave deposits. Meers (1974) suggested a small scale system based on a hair drier and paraformaldehyde tablets and this worked very well in our safety cabinets. Four tablets were almost dispersed in two hr, and the fan warmed the whole cabinet, thus improving the killing rate. The gas concentration in the $0.2 \mathrm{~m}^{3}$ cabinet compared well with that obtained by vaporization of $25 \mathrm{ml}$ neat formalin in $0.38 \mathrm{~m}^{3}$.

Ultraviolet radiation is a misleading and misused routine sterilization process for safety cabinets. The paraformaldehyde system is a simple alternative, readily applicable to small units. Possibly two fans might be needed for a larger one. A simple improvement would be the use of a connexion between the air inlet of the hair drier and the extract ducting of the cabinet above the main filter; this should allow circulation of gas through the filter beforeits replacement. 
This work was carried out as part of a survey on safety cabinets for the DHSS through Inter-Board Study Group 9 of the Engineering Division, whose support we gratefully acknowledge.

\section{References}

Braymen, J. D., and Songer, J. R. (1970). Method for quantitating formaldehyde gas in air. Appl. Microbiol., 19, 1021-2.

Collins, F. M. (1971). Relative susceptibility of acid-fast and nonacid-fast bacteria to ultraviolet light. Appl. Microbiol., 21, 411-413.

Darlow, H. M. (1967). The design of microbiological safety cabinetse
Chemy Ind., 4-5, 1914-1916.

Evans, C. G. T, and Harris-Smith, R. (1970). In Automation, Mechanization and Data Handling in Microbiology, edited by $\mathrm{A}$. Baillie and R. J. Gilbert, pp. 137-149. London.

Gates, F. L. (1928). A study of the bactericidal action of UV light. J. gen. Physiol., 13, 231-260.

Meers, P. D. (1974). Personal communication.

Morris, E. J. (1972). The practical use of ultraviolet radiation for disinfection purposes. Med. Lab. Technol., 29, 41-47.

Shechmeister, I. C. (1968). In Disinfection, Sterilization and Preservation, edited by C. A. Lawrence, and S. S. Block, pp. 761-773. Philadelphia.

Taylor, L. A., Barbeito, M. S., and Gremillion, G. G. (1969). Paraformaldehyde for surface sterilization and detoxification. Appl. Microbiol., 17, 614-618. 